\title{
Stability of single and double layer fibrillar amyloid- $\beta$ oligomers
}

\author{
Anna Kahler, Anselm HC Horn, Heinrich Sticht ${ }^{*}$ \\ From 8th German Conference on Chemoinformatics: 26 CIC-Workshop \\ Goslar, Germany. 11-13 November 2012
}

\begin{abstract}
Alzheimer's disease (AD) is the most common form of dementia world-wide. The causative agent in this protein misfolding disease is the 39 to 42 -residues long amyloid- $\beta$ (A $\beta)$ peptide, that aggregates into oligomers, filaments, and fibrils found in plaque deposits in the brain of $\mathrm{AD}$ patients [1].

Up to now a viable cure for this disease is still not available. One reason for this is $A \beta$ 's conformational flexibility and structural heterogeneity in solution paired with its aggregation tendency. This renders the determination and isolation of distinct $A \beta$ structures experimentally challenging. Especially the soluble oligomers, that are thought to be the neurotoxic species in $\mathrm{AD}$, may adopt a plethora of conformations in vivo [1].
\end{abstract}

It is known from experiment, that there exist toxic fibrillar oligomers, but the details of their topology are not yet known [2]. Thus, we used molecular dynamics simulations to investigate the structural stability of fibrillar single and ouble layer $A \beta 42$ oligomers of different size (4-mer to 48-mer), that we constructed from the experimental structure [3] (cf Figure 1).

We found that there is a clear correlation between oligomer size and preference for double layer structure: Large oligomers display an enhanced stability in double layer conformation, whereas small oligomers prefer the single layer structure. On the other hand, large single layer oligomers dissociate into smaller oligomers, while small double layer oligomers collapse or are energetically unfavorable. From

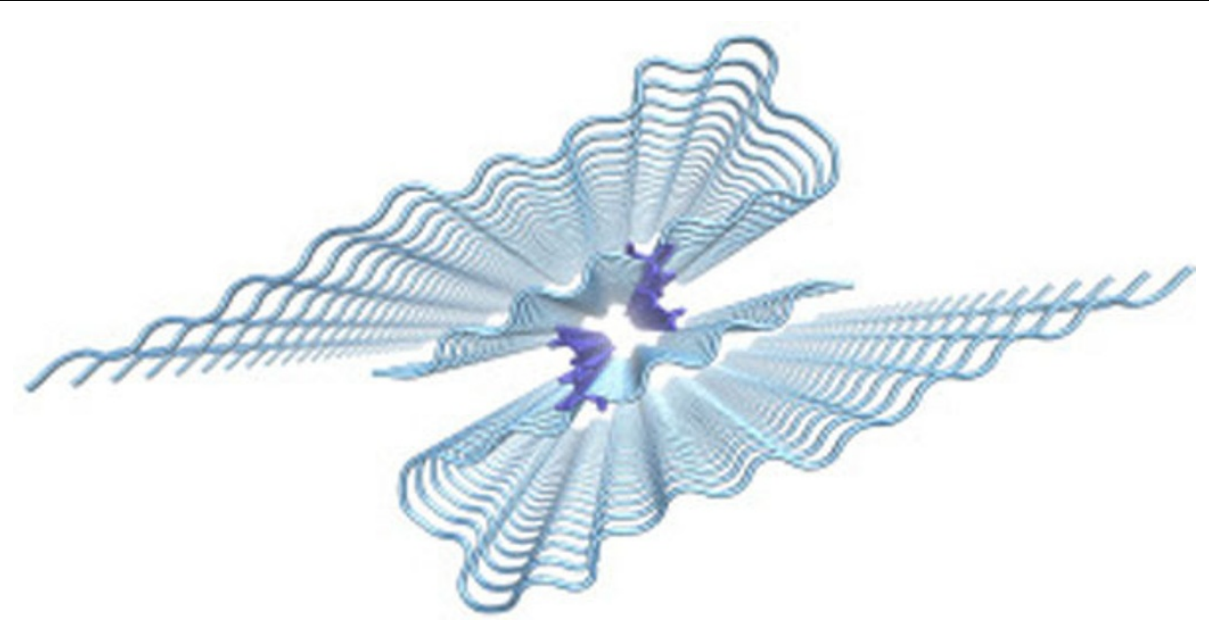

Figure 1 Double layer $A \beta$ 48-mer (Met35 in the interface in sticks representation).

* Correspondence: h.sticht@biochem.uni-erlangen.de

Bioinformatik, Friedrich-Alexander-Universität Erlangen-Nürnberg, Erlangen,

91054, Germany 
our simulations we deduce that the critical number of oligomers to construct a stable $A \beta$ double layer is in the range of 10 to 12 .

In a more general picture, longitudinal growth along a single layer is limited by the increasing structural instability. Lateral growth, i.e. forming a double layer, creates stable mini-fibrils. These may act as seeds for further stable fibril growth.

Published: 22 March 2013

\section{References}

1. Haass C, Selkoe DJ: Soluble protein oligomers in neurodegeneration: lessons from the Alzheimer's amyloid beta-peptide. Nat Rev Mol Cell Biol 2007, 8:101-112.

2. Stroud JC, Liu C, Teng PK, Eisenberg D: Toxic fibrillar oligomers of amyloid- $\beta$ have cross- $\beta$ structure. PNAS 2012, 109:7717-7722.

3. Lührs T, Ritter $C$, Adrian M, Riek-Loher D, Bohrmann B, Döbeli $H$, Schubert D, Riek R: 3D structure of Alzheimer's amyloid-beta(1-42) fibrils. PNAS 2005, 102:17342-17347.

doi:10.1186/1758-2946-5-S1-P9

Cite this article as: Kahler et al: Stability of single and double layer fibrillar amyloid- $\beta$ oligomers. Journal of Cheminformatics 2013 5(Suppl 1): P9.

\section{Publish with ChemistryCentral and every scientist can read your work free of charge \\ "Open access provides opportunities to our colleagues in other parts of the globe, by allowing anyone to view the content free of charge." W. Jeffery Hurst, The Hershey Company. \\ - available free of charge to the entire scientific community \\ - peer reviewed and published immediately upon acceptance \\ - cited in PubMed and archived on PubMed Central \\ - yours - you keep the copyright \\ Submit your manuscript here: \\ http://www.chemistrycentral.com/manuscript/<smiles>c1ccccc1</smiles> 